\title{
RAKYAT DESA, NAGARI, GAMPONG, MARGA, DAN SEJENISNYA MENJADI KORBAN PEMERINTAH DESA DAN PEMERINTAH ATASAN
}

\author{
Hanif Nurcholis
}

\begin{abstract}
Abstrak: Hubungan antara Yang Memerintah dengan Yang Diperintah menciptakan tiga relasi: 1) Yang Memerintah sebagai pelayan kepada warga negara dan Yang Diperintah sebagai penerima layanan publik; 2) Yang Memerintah sebagai penjual barang-barang publik dan Yang Diperintah sebagai pembelinya secara gratis; dan 3) Yang Memerintah sebagai penguasa yang tidak bertanggung jawab dalam memberikan layanan publik dan layanan civil dan Yang Diperintah sebagai korban. Pembentukan pemerintah desa di bawah UU No. 6/2014 menciptakan relasi antara Yang Memerintah dengan Yang Diperintah dimana Yang Diperintah (rakyat desa) sebagai korban. Hal ini terjadi karena desain dan struktur organisasi yang dibangun tidak menjadikan Pemerintah Desa sebagai instrumen pelayanan publik di desa tapi hanya sebagai perantara (tussenpersoon atau mediator) antara Yang Memerintah dengan Yang Diperintah. Pemerintah Desa tidak mempunyai organ yang melayani rakyat desa. Akibatnya rakyat desa tidak mendapatkan pelayanan kesehatan, pendidikan, irigasi, pertanian, perikanan, transportasi publik perdesaan, industri, dan perdagangan. Kegiatan Pemerintah Desa secara aktual hanya mengeluarkan Surat Keterangan, memobilisasi rakyat untuk membangun infrastruktur melalui lembaga korporatis buatan Negara (RT, RW, PKK, LPM, P3A, dan Karang Taruna), menarik pajak, membuat laporan penduduk, dan melaksanakan proyek Pemerintah Atasan. Untuk itu, Pemerintah Desa perlu direformasi menjadi pemerintah lokal otonom modern dengan fungsi menyejahterakan rakyat yang dilakukan dengan cara memberi layanan publik dan layanan civil kepada rakyat desa.
\end{abstract}

Kata Kunci: Yang Memerintah dan Yang Diperintah, perantara (tussenpersoon atau mediator), korban. 


\section{A. PENDAhUluan}

Sesuai dengan teori ilmu pemerintahan hubungan antara rakyat dan pemerintah adalah hubungan antara Yang Memerintah dengan Yang Diperintah. Hubungan ini dapat menciptakan tiga bentuk: 1) Yang Memerintah sebagai pelayan rakyat dan Yang Diperintah sebagai penerima layanan civil dan publik; 2) Yang Memerintah sebagai penjual jasa layanan publik dan Yang Diperintah sebagai pelanggan atau pembeli layanan civil dan publik; dan 3) Yang Memerintah sebagai penguasa yang tidak bertanggung jawab atas layanan civil dan layanan pubik dan Yang Diperintah sebagai korban (Ndraha, 2003). Rakyat sebagai penerima layanan publik jika Yang Memerintah memperlakukan rakyat sebagai warga negara dalam sistem pemerintahan demokratis yang harus diberikan hak-haknya dalam bentuk public services. Rakyat sebagai pelanggan (customer) jika Yang Memerintah menganggap diriya adalah penjual barang-barang publik yang dibeli atau diproduksi dengan menggunakan uang rakyat dan rakyat dianggap sebagai pembeli yang membayar dengan pajak, retribusi, atau subsidi yang diberikan. Rakyat menjadi korban jika Yang Memerintah tidak bertanggung jawab atas layanan publik dan/atau tidak menjual barangbarang publik secara gratis kepada rakyat. Yang Memerintah hanya minta pajak kepada rakyat dan Yang Diperintah disuruh melaksanakan tugas dari Yang Memerintah tanpa mendapatkan hak pelayanan publik atau dapat membeli barang-barang publik secara gratis.

\section{B. RAKYAT DESA, NAGARI, GAMPONG, MARGA, DAN SEJENISNYA SEBAGAI KORBAN}

Berdasarkan teori hubungan pemerintahan tersebut, rakyat desa di bawah pengaturan IGO 1906 Juncto IGOB 1938, Osamu Seirei No. 27/1942, UU No. 5/1979, UU No. 22/1999, UU No. 32/2004, dan UU No. 6/2014 adalah korban, bukan warga negara penerima layanan publik dan juga bukan customer. Sebagai warga negara (citizens) yang berhak menerima layanan publik, rakyat desa menjadi korban karena Yang Memerintah tidak membuat organisasi negara resmi di Desa dengan fungsi menyejahterakan rakyat dengan tugas utama memberikan pelayanan publik kepada rakyat desa. Sebagai customer rakyat menjadi korban karena Yang Memerintah tidak membuka warung pelayanan publik di desa. Yang Memerintah hanya membuat badan pemerintahan bayangbayang/quasi atau badang pemerintahan semu/palu di Desa karena yang didirikan di Desa bukan badan pemerintahan yang sebenarnya. Oleh karena itu, Pemerintah Desa tidak menjual barang-barang publik yang dibutuhkan rakyat desa.

Perlu diketahui bahwa berdasarkan IGO 1906 Juncto IGOB 1938, Osamu Seirei No. 27/1942, UU No. 5/1979, UU No. 22/1999, UU No. 32/2004, dan UU No. 6/2014 Negara tidak 
membentuk organ negara resmi di Desa. Di bawah IGO 1906 Juncto IGOB 1938 Negara membentuk Pemerintahan Haminte Pribumi yang bukan organ pemerintahan resmi. Ia hanya badan hukum sosial-politik yang menjembatani antara kepentingan Yang Memerintah dengan kepentingan rakyat pribumi di perdesaan. Pada zaman pendudukan Jepang di bawah Osamu Seirei No. 27/1942 Negara menjadikan pemerintahan $k u$ dengan tonarigumi, aza, fujingkai, seinendan, heiho, dan kaibodan sebagai alat/instrumen mobilisasi rakyat desa untuk mendukung Perang Asia Timur Raya (Kurasawa, 1993, 2015). Pada zaman Orde Baru dan Reformasi di bawah UU No. 5/1979 Juncto UU No. 22/1999 Juncto UU No. 32/2004 Juncto UU No. 6/2014 Negara menjadikan Pemerintahan Desa dengan RT, RW, LKMD, LPM, P3A, POSYANDU, PKK, Karang Taruna, Hansip, Hanra, dan Linmas sebagai alat/instrumen mobilisasi penduduk desa atas nama partisipasi untuk menyukseskan program pembangunan dan menciptakan ketertiban dan keamaan. Lembaga pemerintah desa dengan RT, RW, LKMD, LPM, P3A, POSYANDU, PKK, Karang Taruna, Hansip, Hanra, dan Linmas bukan organisasi publik yang berfungsi menyejahterakan rakyat dengan tugas memberikan pelayanan publik tapi organisasi sosial-politik bentukan negara yang oleh Schmmitter (1974) disebut state corporatisme, korporasi negara. Secara aktual, fungsi Pemerintah Desa adalah menciptakan keamanan dan ketertiban (rust en orde) dan perantara antara rakyat dengan Pemerintah Atasan (tussenperson). Tugas pokoknya adalah menarik pajak bumi dan bangunan (PBB) dan melaksanakan program dari Yang Memerintah dengan cara memobilisasi rakyat desa melalui badan-badan korporatis bentukan Negara: RT, RW, LKMD, LPM, P3A, POSYANDU, PKK, Karang Taruna, Hansip, Hanra, dan Linmas. Badan-badan korporatis ini bukan badan pelayan publik tapi organisasi yang dijadikan intrumen mobilisasi oleh Yang Memerintah: Musyawarah Pembangunan Desa (Musrenbangdes), Musyawarah Desa, Rapat BPD, "gotong royong" membangun infrastruktur, menimbang anak balita, menyalurkan beras miskin, mendata penduduk, menangani gizi buruk, pemberdayaan perempuan, dan mengurus irigasi.

Jadi, sejak zaman penjajahan, Orde Baru sampai sekarang di Desa tidak dibentuk organ negara resmi dengan fungsi menyejahterakan rakyat dan dengan tugas utama memberikan pelayanan publik kepada rakyat atau menjual barangbarang publik kepada rakyat desa secara gratis. Yang Memerintah hanya membentuk badan hukum sosial-politik di Desa sebagai instrumen untuk memobilisasi rakyat atas nama partisipasi rakyat dalam pembangunan dengan tujuan menyukseskan agenda politik dan ekonominya.

Pemerintah Desa berdasarkan UU No. 5/1979 juncto UU No. 22/1999 juncto UU No. 32/2004 juncto UU No. 6/2014 menciptakan tiga korban sebagai berikut.

1. Rakyat Desa

Rakyat desa menjadi korban pertama karena tidak mendapatkan pelayanan publik berupa 
barang publik dan/atau jasa publik dari Yang Memerintah. Berikut ini adalah ilustrasi rakyat desa yang menjadi korban tersebut. Seorang warga desa usia 18 tahun datang ke Kantor Desa dan melapor kepada Sekretaris Desa, “ Pak Sekdes saya mau minta KTP”. Sekdes lalu memberi Surat Keterangan. Si warga desa berkata, "Pak Sekdes yang saya minta itu KTP bukan Surat Keterangan seperi ini”. "Maaf, Dik, Pemerintah Desa tidak berwenang mengeluarkan KTP. Yang berwenang adalah Dinas Kependudukan dan Catatan Sipil Kabupaten. Pemerintah Desa hanya kantor perantara untuk mendapatkan KTP. Jadi, Adik dengan membawa Surat Keterangan ini datang ke kecamatan lalu ke Dinas Dukcapil Kabupaten.

Para petani datang ke Kantor Desa menemui Kepala Desa dan berkata, "Pak Kades sawah kami tidak airnya. Kami khawatir kalau sampai tiga hari tidak turun hujan tanaman padi kami mati. "Lo kok melapor ke saya. Memang saya Mantri Irigasi. Pemerintah Desa tidak mempunyai tugas mengurusi air untuk pertanian. Silakan lapor ke Dinas Pertanian sana atau Dinas apa gitu di Kabupaten, saya tidak tahu!,” jawab Kepala Desa dengan ketus.

Seorang Ibu dengan menggendong anaknya yang sakit datang ke Kantor Desa lalu berkata, "Pak Kades, anak saya sakit keras. Mohon Bapak dapat membantu anak saya!’. "Mohon maaf, Bu! Pemerintah Desa tidak menyediakan layanan kesehatan. Jadi, Ibu harus ke Puskesmas di Kecamatan”, jawab Kades.

Seorang nelayan datang ke Kantor Desa lalu berkata, "Pak Kades, jembatan di Dukuh Ganten hanyut akibat air bah kemarin. Mohon segera dibangun jembatan baru agar warga Dukuh Ganten bisa keluar dari kampungnya". Kepala Desa menjawab, "Wah maaf Pak. Pemerintah Desa tidak mempunyai kantor Dinas Pekerjaan Umum seperti Kabupaten. Untuk itu, semua warga Dukuh Ganten harus ramai-ramai meperbaiki jembatan. Saya akan mobilisir semua Ketua RT dan RW, tokoh masyarakat, LPM, Linmas, dan seluruh warga untuk "gotong royong" membangun jembatan. Nanti tahun depan kita anggarkan melalui Dana Desa untuk membangun jembatan baru". "Yang akan dibangun sekarang model jembatan apa, Pak?", sahut si Nelayan. "Jembatan bambu”, jawab Kades.

Begitulah potret Pemerintah Desa di bawah UU No. 5/1979 juncto UU No. 22/1999 juncto UU No. 32/2004 juncto UU No. 6/2014. Pemerintah Desa tidak memberi pelayanan dasar kepada rakyat desa bidang pendidikan, kesehatan, irigasi, air minum, kebersihan, utilitas dasar, pertanian, perikanan, dan keamanan. Pemerintah Desa hanya pemberi surat pengantar warga negara dan menarik pajak bumi dan bangunan (PBB). 
2. Kepala Desa

Kepala desa menjadi korban kedua karena statusnya tidak jelas. Kepala Desa diangkat oleh pejabat pemerintah (bupati/wali kota). Akan tetapi, statusnya bukan pejabat pemerintah (government official). Kepala Desa hanyalah kepala badan hukum sosialpolitik bentukan Negara dengan lingkup Desa. Bagi orang yang paham hukum tata negara sungguh kasihan melihat kepala desa. Kepala Desa disuruh memakai atribut-atribut pejabat pemerintah dan dia sendiri merasa dirinya sebagai pejabat pemerintah. Padahal secara hukum kepala desa bukan pejabat pemerintah.

Dengan status yang tidak jelas tersebut kepala desa tidak mendapatkan hak-hak sebagai pejabat pemerintah: gaji, tunjangan jabatan, protokoler, dan pensiun. Kepala Desa hanya mendapatkan honorarium dari tanah jabatan bekas Kerajaan Mataram (untuk kepala desa di Jawa Tengah dan Jawa Timur), honorarium dari Pemerintah Kabupaten/Kota, dan dari Dana Desa.

\section{Perangkat Desa}

Perangkat desa menjadi korban ketiga karena statusnya juga tidak jelas. Perangkat desa bukan bagian dari aparatur sipil negara (ASN) yang terdiri atas Pegawai Negeri Sipil (PNS) dan pegawai pemerintah dengan perjanjian kerja (P3K) sebagaimana diatur dalam UU No. 5/2014. Perangkat desa bukan pegawai honorer kabupaten/kota. Perangkat desa juga bukan pekerja/buruh sebagaimana diatur dalam UU No. 13/2003 tentang Ketenagakerjaan.

Sama dengan kepala desa, perangkat desa juga tidak mendapatkan hak-hak sebagai aparatur sipil negara: gaji, tunjangan jabatan, kenaikan pangkat, pembinaan dan pengembangan, dan pensiun. Perangkat desa hanya mendapatkan hak honorarium dari tanah jabatan bekas Kerajaan Mataram (untuk kepala desa di Jawa Tengah dan Jawa Timur), honorarium dari Pemerintah Kabupaten/Kota, dan dari Dana Desa.

Orang melihat perangkat desa juga kasihan. Mereka diberi atribut-atribut dan pakaian seperti ASN. Tapi sebenarnya bukan ASN. Sudah tahu bahwa perangkat desa bukan ASN tapi Pemerintah memberikan tugas kepada mereka pekerjaan yang bersifat teknokratis dan birokratis. Padahal pekerjaan teknokratis dan birokratis ini adalah tugas yang seharusnya diberikan kepada ASN. Lebih kasiha lagi kalau perangkat desa tidak bisa mengerjakan tugas tersebut dengan benar, Pemerintah Atasan dan masyarakat menyalahkan dan mencaci maki mereka.

\section{PEMERINTAH DESA MENGHALANGI PELAYANAN PUBLIK DARI PEMERINTAH ATASAN}

Sesuai dengan Pembukaan UUD 1945 untuk mencapai tujuan negara yaitu memajukan kesejahteraan umum dan mencerdesakan kehidupan bangsa maka dibentuklah 
pemerintahan negara Indonesia. Jadi, instrumen untuk menyejahterakan dan mencerdaskan kehidupan bangsa adalah pemerintahan yaitu organ resmi negara. Fungsi utama pemerintahan adalah menyejahterakan rakyat melalui pemberian layanan publik kepada citizens (warga negara) berupa barang publik dan jasa publik. Berdasarkan mandat Konstitusi tersebut maka seharusnya Negara membentuk pemerintahan yang bisa menjangkau seluruh lapisan masyarakat sampai ke desa. Akan tetapi, Negara tidak membentuk pemerintahan sampai ke desa. Akibatnya Negara tidak memberi pelayanan publik kepada warga negara yang tinggal di desa.

Perlu diketahui model pemerintahan NKRI saat ini meniru model pemerintahan kolonial Hindia Belanda dengan sedikit perubahan. Sebagaimana pemerintah kolonial, NKRI tidak membentuk pemerintahan sampai di desa. Pada zaman kolonial pemerintahan terdiri atas pemerintah pusat, pemerintah provinsi, pemerintah karesidenan, Pemerintah Kabupaten/Kota (regentschapen/ stadsgemeente), pemerintah kawedanan (district), dan pemerintah asisten wedana (onder district). Di bawah asisten wedana tidak ada pemerintahan formal, yang ada adalah pemerintahan tidak langsung (indirect bestuurd gebied) dengan istilah Pemerintahan $\begin{array}{lrr}\text { Haminte } & \text { Pribumi/Bumiputra } & \text { (Inlandsche } \\ \text { Gemeente). } & \text { Pemerintahan } & \text { Haminte }\end{array}$ Pribumi/Bumiputra bukan pemerintahan resmi tapi korporasi atau rechtspersoon (badan hukum) komunitas pribumi desa yang dibentuk oleh Negara dengan ordonansi (IGO 1906 dan IGOB 1938). Berdasarkan pengaturan demikian,
Negara tidak berurusan langsung dengan rakyat desa. Untuk berurusan dengan rakyat desa, Negara harus melalui kepala korporasi komunitasnya: lurah (kepala desa) sebagai perantara (tussenpersoon atau intermediaries). Di sini kepala desa berfungsi sebagai perantara (tusschenperson atau broker) antara kepentingana rakyatnya dengan kepentingan Pemerintah Atasan dan sebaliknya. Regent/Bupati dan bawahannya tidak bisa berhubungan dengan rakyat desa. Untuk berhubungan dengan rakyat desa, Regent/Bupati dan bawahannya harus melalui kepala desa sebagai perantaranya (tusschenperson atau broker). Sebaliknya, rakyat desa juga tidak bisa berhubungan langsung dengan Bupati. Semua kepentingan rakyat desa harus diserahkan dulu kepada kepala desa sebagai brokernya. Begitu juga Bupati. Semua kepentingan Pemerintah Kabupaten yang berhubungan dengan rakyat desa seperti penarikan pajak bumi, tugas wajib kerja, pelaksanaan pendidikan dasar, kredit tani, dan pelaksanaan lumbung padi, harus dengan perantara kepala desa melalui pejabat resminya: Asisten Wedana (Onghokham, 1975: 162-166).

Mirip dengan zaman kolonial, berdasarkan UU No. 23/2014 struktur organisasi pemerintahan terdiri atas Pemerintah Pusat, Pemerintah Provinsi, dan Pemerintah Kabupaten/Kota. Di bawah Kabupaten/Kota tidak ada pemerintahan formal, yang ada adalah pemerintahan tidak langsung (indirect bestuurd gebied) dengan istilah Pemerintahan Desa dan Pemerintahan Desa Adat. Pemerintahan Desa dan Pemerintahan Desa Adat bukan pemerintah 
formal tapi korporasi sosial-politik di Desa yang dibentuk oleh Negara dengan UU No. 6/2014. Sebagai korporasi, Pemerintah Desa mempunyai jurisdiksi sendiri yang tidak bisa diintervensi langsung oleh Pemerintah Kabupaten/Kota. Berdasarkan pengaturan demikian, Negara tidak bisa berurusan langsung dengan rakyat desa. Untuk memberi pelayanan publik kepada rakyat desa, Negara harus melalui kepala korporasinya (kepala desa) sebagai tussenperson atau broker. Kepala desa adalah kepala badan hukum semi otonom yang mewakili masyarakat desa. Ia bukan bawahan bupati/walikota. Ia sama-sama kepala badan hukum menurut Undang-Undang. Bupati/walikota adalah kepala badan hukum pemerintah lokal/daerah otonom sedangkan kepala desa adalah kepala badan hukum sosialpolitik desa. Oleh karena itu, bupati/walikota tidak bisa memberi perintah langsung kepada kepala desa untuk melaksanakan tugas bupati/walikota karena bukan aparatur bawahannya. Kepala desa bisa menolak perintah bupati jika materi perintahnya tidak sesuai dengan UU No. 6/2014.

Masalah menjadi rumit karena status badan hukum desa bukan badan hukum pemerintah lokal/ daerah otonom (local self-government) sebagaimana kabupaten/kota. Hal ini berbeda dengan provinsi dan kabupaten/kota yang samasama badan hukum pemerintah lokal/daerah otonom. Oleh karena itu, Provinsi dan Kabupaten/Kota menyelenggarakan urusan pemerintahan yang segaris/linear. Tidak demikian dengan Pemerintah Desa. Urusan pemerintahan yang diselenggarakan Pemerintah
Desa tidak segaris atau berbeda dengan urusan pemerintahan yang diselenggarakan Kabupaten/Kota dan Provinsi. Pemerintah Desa tidak mengurus pendidikan, kesehatan, pekerjaan umum dan penataan ruang, perumahan dan kawasan permukiman, irigasi, perdagangan, industri, dan seterusnya. Pemerintah Desa hanya mengatur dan mengurus urusan asal-usul dan urusan skala lokal. Urusan inipun tidak ada organ yang mengurusnya karena struktur organisasi Pemerintah Desa tidak dilengkapi dengan organ pelaksana urusan. Akibatnya pelayanan publik bidang pendidikan, kesehatan, pekerjaan umum dan penataan ruang, perumahan dan kawasan permukiman, dan seterusnya tidak diurus oleh Pemerintah Desa karena Pemerintah Desa tidak mempunyai kewenangan mengurusnya. Karena tidak mengurus bidangbidang tersebut maka Pemerintah Desa tidak mempunyai dinas pendidikan, dinas kesehatan, dinas pengairan, dan seterusnya sebagai pelaksana urusan pemerintahan yang linear dengan urusan pemerintahan yang diselenggarakan kabupaten/kota. Pemerintah Desa hanya mempunyai kepala desa dan perangkat desa sebagai organ korporasi sosialpolitik. Sementara itu, Pemerintah Kabupaten/Kota tidak bisa masuk langsung ke Desa karena terhalang oleh status desa sebagai badan hukum (korporasi). Ia bukan local selfgovernment di bawah koordinasi kabupaten, bukan local state-government, bukan OPD (organisasi perangkat daerah) Kabupaten/Kota, dan bukan subordinat Pemerintah Kabupaten/Kota. Pemerintah Desa adalah 
korporasi sosial-politik semi otonom di bawah Pemerintah Kabupaten/Kota yang mempunyai jurisdiksi dan sistem kerja sendiri.

Pemerintah Desa mempunyai mekanisme sendiri dan berdiri sendiri. Ia mempunyai lembagalembaga mirip dengan lembaga-lembaga Kabupaten/Kota: 1) kepala desa mirip dengan bupati/walikota; 2) BPD mirip dengan DPRD; 3) Peraturan Desa (Perdes) mirip dengan Peraturan Daerah (Perda); 4) APBDesa mirip dengan APBD; 5)Rencana Pembangunan Jangka Menengah (RPJM) Desa mirip dengan RPJM Kabupaten/Kota; dan 6) Rencana Kerja (RK) Desa mirip dengan RK Kabupaten/Kota. Kebijakan umum dibuat dalam bentuk Perdes yang dibuat oleh Kepala Desa dan BPD. Perdes dioperasionalkan dengan Peraturan Kepala Desa. Pemerintah Desa harus membuat Perdes tentang RPJM. RPJM dibuatkan lagi Perdes tentang RK dan APBDesa tiap tahun. Akan tetapi, program yang dibuat dalam RPJM, RK, dan APBDesa hanya legitimasi atas kebijakan yang telah dibuat oleh pemerintah pusat melalui Peraturan Menteri. Semua kebijakan tersebut hanya berputar-putar pada kegiatan sehari-hari pemerintahan desa: 1) menarik pajak bumi dan bangunan; 2) membangun infrastruktur; 3) menjadi perantara permohonan surat-surat resmi ke pemerintah atasan; 4) memobilisasi perempuan ikut PKK dan Posyandu; 5) memobilisasi anggota BPD, ketua RT, ketua RW, dan anggota LPM mengikuti rapat desa membuat Perdes dan lain-lain; 6) memobilisasi warga desa untuk kerja wajib/gotong royong (heerendiensten), dan 7) melaksanakan tugas pemerintah atasan. Ketujuh kegiatan pemerintahan sehari-hari tersebut didanai Dana Desa (DD) dan Alokasi Dana Desa (ADD) dengan jumlah sangat besar (milyaran).

Penggunaan DD dan ADD tersebut saat ini bermasalah karena banyak dikorupsi dan disalahgunakan oleh kepala desa dan pemangku kepentingan. Hal ini terjadi karena Pemerintah Desa yang hanya korporasi komunitas diurus oleh kepala desa, perangkat desa, anggota BPD, dan lembaga kemasyarakatan warisan Jepang dan Orde Baru. Lembaga ini tidak mempunyai kapasitas mengelola DD dan ADD karena sumber daya manusianya tidak kompeten. Kepala desa diisi dengan cara pemilihan langsung dari warga desa yang rendah pendidikannya sedangkan perangkat desa diisi dengan cara seleksi dan pengangkatan yang tidak berdasarkan UU No. 5/2014 tentang ASN. Perangkat desa terdiri atas sekretaris desa, kepala-kepala urusan, kepala dusun, dan staf teknis. Semuanya staf dengan kompetensinya sangat rendah karena direkrut tidak berdasarkan standar ASN tapi berdasarkan standar komunitas sehingga tidak mampu melaksanakan program yang birokratis dan teknokratis. Kedua, Pemerintah Desa tidak mengurus urusan-urusan pemerintahan yang jelas. Akibatnya, Pemerintah Desa tidak membuat penganggaran berdasarkan rumus money follow functions. Pemerintah Desa tidak mempunyai fungsi-fungsi pemerintahan yaitu urusan-urusan pelayanan publik yang harus dilaksanakan. Oleh karena itu, Pemerintah Desa menjadi bingung sendiri ketika harus membuat program dengan uang yang sangat besar. 
Untuk mengatasi ketidakmampuan dan kebingungannya, Pemerintah memberi tenaga pendamping. Lalu agar DD dan ADD tidak dikorupsi maka Pemerintah menugaskan Inspektorat (Kabupaten/Kota/Provinsi/Pusat), kepolisian, dan Komando Teritorial Militer untuk mengawasi. Cara mengatasi masalah dengan cara asal-asalan tersebut tentu tidak mengatasi masalah karena masalahnya terletak pada status desa yang tidak jelas jenis kelaminnya, kompetensi dan profesisonalitas kepala desa dan perangkatnya, kewenangan yang tidak segaris dengan kewenangan Pemerintah Kabupaten/Kota, statusnya yang hanya sebagai badan hukum sosial-politik (bukan organ pemerintahan resmi), tiadanya urusan pemerintahan dasar yang dimiliki oleh pemerintah desa, dan tiadanya lembaga pelaksana urusan pemerintahan yang memberikan pelayanan barang dan/atau jasa publik kepada warga desa sesuai dengan kepentingan dan kebutuhannya.

Dana Desa dan ADD yang sangat besar tersebut akan bernasib sama dengan dana Bantuan Desa (Bandes) dan dana IDT (Inpres Desa Tertinggal) zaman Orde Baru. Perlu diketahui bahwa Pemerintah pada Pelita I (1969-1974) telah menyalurkan dana desa sebesar Rp 100.000,00 dan berakhir pada 1999 sebesar Rp 10.000.000,00 setiap tahun. Kemudian pada 1995-1998 Pemerintah juga menyalurkan dana desa IDT sebesar Rp 20.000.000,00 untuk desa miskin. Semuanya menguap tanpa hasil atau tidak berdampak kepada peningkatan kesejahteraan warga desa. Kebijakan Dana Desa dan ADD inipun tampaknya bernasib sama. Rakyat desa tetap tidak bisa sejahtera karena penggunaan Dana Desa tidak ditujukan untuk memberi pelayanan publik dasar kepada warga negara yang tinggal di desa.

Dalam kondisi Pemerintah Desa yang tidak kompeten dan bingug sendiri, Pemerintah Kabupaten/Kota tidak bisa berbuat banyak karena terhalang oleh status Pemerintah Desa sebagai badan hukum semi otonom yang mempunyai jurisdiksi sendiri. Pemerintah Kabupaten/Kota hanya bisa mengurus dirinya sendiri yang tidak bersentuhan langsung dengan kepentingan warga desa. Pemerintah Kabupaten/Kota hanya bisa menitipkan SD pada tiap desa, menempatkan bidan desa untuk melayanai beberapa desa, mendirikan Puskesmas untuk melayani beberapa desa, mendirikan SMP untuk melayani beberapa desa, dan membangun infrastruktur (jalan, jembatan, dan bangunan irigasi) dalam jurisdiksinya. Pemerintah Kabupaten tidak bisa memberikan pelayanan publik langsung kepada warga desa berupa infrastruktur fasilitas umum dan sosial, infrastruktur ekonomi (sarana dan prasarana ekonomi, dukungan permodalan, akses pemasaran, dan dukungan produksi dan sumber daya), sanitasi, air bersih, sampah, transportasi publik, air petani/irigasi, pemberdayaan masyarakat, dan pelayanan perlindungan (rasa tenteram, tertib, dan aman). Kalau akan memberi pelayanan barang dan jasa publik tersebut Pemerintah Kabupaten/Kota harus bernegosiasi dengan kepala badan hukumnya (kepala desa). 
Kondisi desa tersebut sama dengan kondisi desa pada zaman Belanda sebagaimana dijelaksan oleh Joeniarto $\mathrm{SH}$, pakar hukum tata negara Universitas Gadjah Mada. Joeniarto (1967: 66) menjelaskan bahwa kebijakan pemerintah Hindia Belanda dalam menyelenggarakan Pemerintahan Desa sebagaimana diatur dalam IGO 1906 dan IGOB 1938 hanya untuk keuntungan bangsa Belanda saja. Dengan cara menyelenggarakan pemerintahan tidak langsung (indirect bestuurd gebied) maka penguasa yang berbangsa Belanda tidak perlu memberikan pelayanan publik kepada rakyat desa dengan cara menggaji pengurusnya dan membiayai pelayanan publik untuk menyejahterakan penduduk desa. Penguasa hanya mengawasi saja. Penguasa tidak mengurus rakyat desa. Masyarakat desa disuruh mengurus dirinya sendiri bermodalkan tanah komunal warisan Kerajaan Mataram dan kebijakan tanam paksa. Meskipun tidak mengeluarkan ongkos banyak tapi Penguasa tetap bisa mencengkeram penduduk desa dan tanahnya untuk kepentingan politik dan ekonomi bangsa Belanda. Model ini yaitu Penguasa tidak mau mengurus rakyat desa dengan menggaji pengurusnya sesuai dengan standar ASN dan memberikan pelayanan publik dasar kepada penduduk desa diteruskan sampai sekarang di bawah UU No. 6/2014.

Warga negara yang tinggal di kota besar yang sudah tidak memiliki Pemerintah Desa lebih beruntung karena Pemerintah Kota dapat berhubungan langsung dengan citizens yang tinggal di wilayahnya. Semua wilayahnya adalah jurisdiksinya. Tidak ada wilayahnya yang menjadi jurisdiksi pemerintah desa. Karena tidak ada Pemerintah Desa maka pemerintah kota tidak perlu melakukan tawar menawar dengan kepala korporasi sosial politik (kepala desa) di wilayahnya. Pemerintah kota bisa langsung mengesekusi kebijakan dan program untuk warga negara yang tinggal di wilayahnya sampai akar rumput tanpa terhalang oleh badan hukum sosial-politik (pemerintah desa) sebagamana pemerintah kabupaten.

\section{Penutup}

Pemerintah Desa yang diatur oleh UU No. 6/2014 asal-usulnya adalah Pemerintah Haminte Pribumi zaman kolonial yang diatur oleh IGO 1906 juncto IGOB 1938. Pemerintahan jenis ini bukan pemrintahan formal tapi badan hukum sosial-politik buatan Negara yang dijadikan alat oleh Negara untuk mencapai tujuan politik dan ekonominya melalui kontrol dan mobilisasi. Ia bukan alat Negara untuk menyejahterakan rakyat melalui pemberian layanan publik dan layanan civil. Saat ini Pemerintah Desa dijadikan alat Negara untuk melaksanakan proyek infra struktur dengan pembiayaan Dana Desa secara masif. Pemerintah Desa tetap tidak memberi pelayanan dasar kepada rakyat desa. Akibatnya rakyat desa yang masih miskin sangat banyak.

Pemerinah Desa perlu direformasi menjadi badan publik dengan fungsi menyejahterakan rakyat dan tugasnya adalah memberikan pelayanan publik dan civil kepada rakyat desa. Tugas Pemerinitah Desa bukan mengeluarkan Surat Keteranga, menarik pajak, dan memobilisasi rakyat mengerjakan infra struktur tapi memberikan pelayanan publik yang 
dibutuhkan rakyat desa: pendidikan, kesehatan, irigasi, air minum, pertanian, perikanan, listrik, transportasi publik perdesaan, industri perdesaan, perdagangan tingkat desa, kerajinan, dan bank desa. 


\section{DAFTAR PUSTAKA}

Denhardt, Janet Vinzant dan Denhardt, Robert B (2003). The New Public Service:

Serving, Not Steering. New York:

M.E. Sharpe, Inc.

Joeniarto. (1967). Pemerintahan Lokal (Asas

Negara Kesatuan Dengan

Otonomi Yang Seluas-luasnya dan

Perkembangan Serta Pokok-

Pokok Pemerintahan Lokal).

Yogyakarta: Yayasan Badan

Penerbit Gadjah Mada

Yogyakarta.

Kurasawa, Aiko. (1993). Mobilisasi dan Kontrol, Studi tentang Perubahan Sosial di Pedesaan Jawa 1942-1945.

Jakarta: Grasindo . (2015). Kuasa Jepang di Jawa.

Perubahan Sosial di Pedesaan 1942-1945. Depok: Komunitas Bambu

Ndraha, Taliziduhu. (2003). Kybernology (Ilmu Pemerintahan Baru). Jakarta: Reineka Cipta.

Onghokham. (1975). The Residency of Madiun Priyayi and Peasant in The Nineteenth Century. USA: Yale University.

Schmitter, Philippe C. (1974). "Still the Century of Corporatism?" The Review of Politics, Vol. 36, No. 1, The New Corporatism: Social and Political Structures in the Iberian World (Jan., 1974), pp. 85-131. UK: Cambridge University Press for the University of Notre Dame du lac

Undang-Undang Dasar 1945 (Sebelum

Amandemen)

Undang-Undang Dasar 1945 (Sesudah

Amandemen)

Undang-Undang Nomor 5 Tahun 1979 tentang Pemerintahan Desa

Undang-Undang Nomor 22 Tahun 1999 tentang Pemerintahan Daerah
Undang-Undang Nomor 32 Tahun 2004 tentang Pemerintahan Daerah

Undang-Undang Nomor 11 Tahun 2006 tentang Pemerintahan Aceh

Undang-Undang Nomor 23 Tahun 2014 tentang Pemerintahan Daerah

Undang-Undang Nomor 5 Tahun 2014 tentang Aparatur Sipil Negara

Undang-Undang Nomor 6 Tahun 2014 tentang

Desa

Inlandsche Gemeente Ordonnantie 1906

Inlandsche Gemeente Ordonnantie

Buitengewesten 1938 